\title{
Spiritual Vocation and Academic Satisfaction of Senior High School Student
}

\author{
Jerald C. Moneva \\ Department of Education-Mandaue City Division \\ Mandaue City, Cebu, Philippines \\ E-mail: Freezingfire1979@gmail.com \\ Kem Angelo Campos \\ Jagobiao National High School \\ Jagobiao, Mandaue City, Cebu, Philippines \\ E-mail: Kemcampoa@gmail.com
}

Leo B. Acibar

Cebu City, Philippines

E-mail: leo.acibar@deped.gov.ph

Received: March 2, 2020 Accepted: May 22, 2020 Published: June 20, 2020

doi:10.5296/ijssr.v8i2.17218ＵRL: http://dx.doi.org/10.5296/ijssr.v8i2.17218

\begin{abstract}
Spiritual vocation is a broad concept that affects the human spirit or soul that collides the sense of connection to the people giving a bigger meaning in life. Vocation is a work that people feel to do, particularly people want to fulfill a particular role in life. Meanwhile, academic satisfaction is the whole experience of the students and also their expectation regarding to their academic reality. The study intends to assess the association between students' spiritual vocation and academic satisfaction particularly to find out the students' association between students' spiritual vocation and students' academic satisfaction. The study banked the theory proposed by John Holland titled Vocational Choice Theory and Alexander Astin titled Students Involvement Theory. This quantitative approach research used descriptive survey design used rating scale research instruments in gathering the data.
\end{abstract}




\section{Macrothink}

The respondents of the study were the Senior High School Students with a total population of 245 but only 194 students acceded to answer. The researchers asked permission from the students to be the respondents of this research study using informed letter signed by the principal and teachers involved. The researchers provided answer sheets to the respondents to answer. The researcher gave instructions and discussed the purpose of the study before allowing the students to answer the survey questionnaires. The researchers gave at least 10 minutes to answer the questionnaire. The result of the study revealed that there is no association between the students' spiritual vocation and academic satisfaction.

Keywords: spiritual vocation, academic satisfaction, students 


\section{Rationale}

Spiritual vocation is a broad concept that affects the human spirit or soul that collides the sense of connection to the people and gives a bigger meaning in our life. Vocation is a work that people feel to do, particularly people want to fulfill a particular role in life. While, spiritual vocation is the occupation that encompass a person to satisfy a personal calling. Meanwhile, academic satisfaction is one of the most important factors that should consider the main reason that students' academic achievement gets affected. Academic satisfaction is the whole experience of the students and also their expectation regarding to their academic reality.

Higher education is the beginning to the possible need to assist students in the search for meaning and each purpose (Greenway, 2006). Although the implications of each framework are equally important, it is the concept of teaching as a vocation that lends itself to a distinctively Christian or catholic identity in denominational institutions of higher education, (Buijs, 2005). Moreover, spiritual well-being could be considered as main part of health in the curricular programs of medical and social science (Alorani, 2017).

In this study, the researcher intends to determine the relationship between spiritual vocation and academic satisfaction of Senior High School Students. This study intends to know about how students can apply their Spiritual Vocation to their Academic Satisfaction towards their studies.

The researchers observe that students are high in spiritual vocation in terms of attending mass to show a particular activity about serving to God. It is also observed that students especially Senior High School Students can accept any academic matters without any regret or any doubt on their academic performance. They can also use their spiritual vocation to boost their academic satisfaction and be motivated to learn and attend class. The study intends to assess the association between student's spiritual vocation and academic satisfaction.

\subsection{Theoretical Background}

The study is supported with the two theories, the vocational choice theory which is proposed by John Holland and the student's involvement theory which is proposed by Alexander Astin. The vocational choice theory is about how students choose their career vocationally while the student's involvement theory explains the relation of student's changes and development into how society viewed higher education.

Vocational choice theory is one of the most widely researched and applied theories of career development. This theory postulate that people project self and world-of-work views into occupational titles and makes career decisions that satisfy their preferred personal orientations (Holland, 1959).

In order for the students to have satisfaction in academic students should assess their individual interest from the three primary perspectives given by Holland on this theory Holland has maintained that these factors correlate with the clarification and focus of individual's vocation personalities.

The second theory is the student's involvement theory. This theory explains how describe out comes for society or organization of higher education are viewed is relation to have students 
charge and develop. The study focused on third elements of the theory which is the outputs that's state the student's characteristics, knowledge, attitude, beliefs and values (Astin, 1985). In order for the students to get satisfaction in life as student, students usually prefer on their beliefs and values. Most of the students especially catholic students consider vocation as a calling. With that kind of beliefs, characteristics, knowledge and values, most of the students are having satisfaction in academic.

\subsection{Statement of Purpose}

This study aims to assess the correlation of Spiritual Vocation and Academic Satisfaction of Senior High School Students in Jagobiao National High School 2019-2020.

In particular, this study aims to answer the following question.

1) What is the profile of the performance of students in spiritual vocation test?

2) What is the level of Academic Satisfaction towards students?

3) Is there an association between the Spiritual Vocation of the students towards on their Academic Satisfaction?

\subsection{Review of Related Literature}

\section{Spiritual Vocation}

The role of spirituality can either have a positive or negative impact to a person's satisfaction in work (Malik \& Naeem, 2010). Spirituality and the sense of vocation are needed to be nurtured and practiced day-to-day especially to those teachers who are more prone ins giving judgments based on their experiences (Shields, 2008). Among teacher, higher education can be one of the ways to assist the students in the search for meaning and purpose of their chosen vocation (Greenway, 2006). The more the students are spiritual and religious, the more they are into obtaining academic excellence (Owusu-Boateng \& Osei, 2016). However, there is a big possibility that spiritual intelligence will create anxiety to leaders who are in their way of proving themselves in giving a good academic performance (Howard \& White, 2016). In addition, people who believe and who are really into vocational calling are more satisfied with the work they are engaged in (Kent, Bradshaw, \& Dougherty, 2015). Women are more engaged in a work that is in the basis of their spirituality wherein they feel that their work has a higher purpose (Lazar, Davidoritch, \& Coren 2016). Moreover, if a person is in vocational journey, that persons lose his or her life and self and gain a new life with a clean and pure soul (Thompson \& Miller-Perrin, 2012). When a man lost his spirituality and consciousness link to God's presence will lead the man in a situation where in he feels he is unessential and living temporarily (Snati, 2014). Vocation is not needed to be understood religiously unlike with the service or calls that are reserved for those religiously minded (Bujis, 2005). However, in the medical and social sciences, being spiritual could be a main part of a person's health (Alorani \& Alradaydeh, 2018). Unfortunately, the immersion of spirituality and academic performance is not really explored or studied.

\section{Academic Satisfaction}

There is a big difference between students who are unsatisfied with their academic studies and student who are already satisfied from the very beginning (Wach, Karbach, Ruffing, 
Brunken, \& Spinath, 2016). A student is satisfied with his or her life; there is a big possibility that the student will gain also academic satisfaction and more connected to school (Wilcox \& Nordstokke, 2019). Students' expectations on their achievements and how they value the subject is a good motivation that could help student achieve academic satisfaction (Betoret, Rosello, \& Artiga, 2017). One of the factors that could influence students' satisfaction is social areas, auditoriums and libraries (Weerasinghe \& Fernando, 2017). Also, students' academic satisfaction could possibly depend on teachers' way of teaching (Butt \& Rehman, 2010; Keshavarzi \& Ahmadi, 2013). It is proven that emotional intelligence and academic engagement has importance on predicting or determining academic satisfaction (Urquij \& Extremera, 2017). A person with resilience also shows better academic performance and success (Taj, Hussain, Afzal, \& Gilani, 2019). Moreover, the importance of high school success, personality, traits and emotional competence can also determine students' academic success and study satisfaction (Anticeric, Kardum, Klarin, Sindik, \& Barak, 2017). Fortunately, if a student has academic satisfaction there is a possibility that the student will be away from retention and will have academic achievement (Dhagane \& Afrah, 2016).

\section{INSIGHTS}

Students focus more on spiritual vocation to improve their disposition in doing good. It will develop their attitude to keep motivated to perform well in class. Students should believe and prove to themselves that they can value other students and give some tips based on their experiences. The students who help other individuals to know that spiritual vocation can develop their strategy in learning in different aspects and project a good perspective to their career. Meanwhile, student's academic satisfaction can help them achieve academic success because being satisfied in academics only depends in the mindset of the students. Researchers believed that students need to constantly and consistently involve themselves in academic activities and task to develop the appropriate attitude like being responsible in which consequently lead them to academic satisfaction.

\section{Research Method}

\subsection{Design}

This research study used quantitative approach descriptive survey design of the two variables, Spiritual vocations and Academic satisfaction of senior higher school students.

\subsection{Environment}

The research was conduct in Jagobiao National High School, especially Senior Department. The grade 12 classroom were in the new building that includes grade 11 Stem. The Jagobiao National High School offer strands which in Humanities and Social Sciences (HUMSS), General Academic Strand (GAS), Accountancy and Business Management (ABM) and Science Technology Engineering and Mathematics.

\subsection{Respondents}

The respondents of the study were the Senior High School Students with a total population of 194. The respondents were chosen from the Senior High School students particularly in Grade 11 and Grade 12 students. HUMSS 12 has 38 respondents, GAS 12 has 23 respondents, 
ABM has 29 respondents, HUMSS 11 has 40 respondents, STEM 11 has 39 respondents, and ABM 11 has 25 total respondents.

\subsection{Instruments}

For this study, the researcher used the result of the respondents' National Career Assessment Examination (NCAE) particularly in their Spiritual Vocation for the first variable which is spiritual vocation and academic satisfaction for the second variable. The researcher used a checklist consisting of 10 indicators. The researcher will rate the answers through the rating scale given on the checklist which are Strongly Agree (4), Agree (3), Disagree (2) and Strongly Disagree (1). The indicators and the rating scales of the second variable were made by the researcher. The categories under spiritual vocation are not knowledgeable, slightly knowledgeable, fairly knowledgeable, moderately knowledgeable, and highly knowledgeable. Categories under academic satisfaction are least satisfied, fairly satisfied, Satisfied, and highly satisfied.

\subsection{Data Gathering Procedures}

The researcher asked permission from the students to be the respondents of this research study with the help of transmittal letter signed by the principal and teachers involved. The researcher will provide an answer sheet for the respondents to answer. The researcher will give instructions and will discuss the purpose of the study before allowing the students to answer the given survey questionnaires. The researcher will give the respondents at least 10 minutes to answer the given questionnaires.

After answering the question, the researcher will collect the entire questionnaire and it will serve as the basis in making the analysis, interpretation, pin dings, conclusion and recommendation of the study.

\subsection{Statistical Treatment}

The researcher used weighted mean, sum, frequency, percentage and chi-square to treat the data gathered. The weighted mean was used to get the mean of the level of students' academic satisfaction. The study used Chi-Square test to determine whether there is significant association between the expected frequencies and the observed frequencies in one or more categories. 


\section{Al Macrothink

\subsection{Data Analysis and Discussion}

Table 1. Spiritual vocation

\begin{tabular}{lll}
\hline Category & Frequency & Percentage \\
\hline Not Knowledgeable & 0 & 0 \\
Slightly Knowledgeable & 31 & 16.0 \\
Fairly Knowledgeable & 47 & 24.2 \\
Moderately Knowledgeable & 53 & 27.3 \\
Highly Knowledgeable & 63 & 32.5 \\
TOTAL & $\mathbf{1 9 4}$ & $\mathbf{1 0 0}$ \\
\hline
\end{tabular}

Scale: (1-20) Not Knowledgeable; (21-40) Slightly Knowledgeable; (41-60) Fairly Knowledgeable; (61-80) Moderately Knowledgeable; (80-100) Highly Knowledgeable.

This table shows that out of 194 students, 63 respondents have a high knowledge about spiritual vocation with a percent of 32.5 percent of a sample. The respondents have a moderate knowledge about spiritual vocational with a frequency of 58 and has a percentage of 27.3 while 47 respondents have a fairly knowledge about spiritual vocation with a frequency of 31 and have 24.2 percentage. The researchers observed that most students are highly knowledgeable towards spiritual aspect. Hence, the result showed that none of the respondents fall under "not knowledgeable category towards spiritual vocation. It is important to apply the spirituality and sense of vocation in school" (Shields, 2008). For the reason education can be one of the factors that will help the students to be more into spirituality (Greenway, 2006). In addition, there is a big possibility that students will obtain academic excellence if they are spiritual and religious (William \& Isaac, 2016). It is believed by majority that if students are spiritually inclined, the more they are attached to God. With that, positive values towards their students are manifested in them. 
Table 2. Academic satisfaction

\begin{tabular}{|c|c|c|}
\hline Indicator & W. M & Interpretation \\
\hline 1. Teacher stimulates me to understand information. & 3.22 & Agree \\
\hline 2. Teacher makes it possible for us to achieve learning objectives. & 3.24 & Agree \\
\hline 3. Teacher answers question and problems during class. & 3.36 & Strongly Agree \\
\hline 4. Teacher methods or strategies in teaching are effective. & 3.24 & Agree \\
\hline 5. Teacher clearly defines the subject objectives. & 3.31 & Strongly Agree \\
\hline $\begin{array}{l}\text { 6. Teacher uses example that would make me appreciate the } \\
\text { relevance of the subject. }\end{array}$ & 3.35 & Strongly Agree \\
\hline $\begin{array}{l}\text { 7. Teacher stimulates my abilities and supports them on how I use } \\
\text { it to judge or give opinions on the subject. }\end{array}$ & 3.20 & Agree \\
\hline 8. Teacher is available for questions even if it is not a class hour. & 3.25 & Agree \\
\hline 9. Teacher explain about the subject is clear and well-organized. & 3.33 & Strongly Agree \\
\hline $\begin{array}{l}\text { 10. Teacher stimulates my intellectual curiosity and my desire to } \\
\text { learn. }\end{array}$ & 3.33 & Strongly Agree \\
\hline OVERALL WEIGHTED MEAN & 3.28 & Strongly \\
\hline
\end{tabular}

Note. Scale: 1.00-1.75 (Strongly Disagree); 1.76-2.50 (Disagree); 2.51-3.25 (Agree); 3.26-4.00 (Strongly Agree).

This table shows that the overall weighted mean is 3.28. Students strongly agree that they are academically satisfied. The biggest average is the indicator 3 with average of 3.36, which states that "teachers answer question and problems during class". With average 3.35 the indicator states that "teacher uses example that would make them appreciate the relevance of the subject", and students strongly agree. The indicators that has third biggest average are indicators 9 and 10 with average of 3.33 that states students strongly agree that teacher explain about the subject is clear and well-organized and teacher stimulates their intellectual curiosity and their desire to learn. The researchers observed that students become satisfied with their academic for students preferred the way their teachers taught them come be more productive in school and gain high level of academic performance. Teachers' way of teaching has significant and positive impact on enhancing students' academic satisfaction (Butt \& Rehman, 2010). Thus, if the students are dissatisfied in academics, it could result info some, personal and social problems (Keshavarzi \& Ahmadi, 2013). The lowest weighted mean is the indicator 2 with average of 3.24 which states that agree that "teacher makes it possible for them to achieve learning objectives" and student agree. The second indicator with lowest average is indicator 1 with average of 3.22 which states that teachers stimulate them to understand information. The indicator that has third lowest average is indicator 7 with average of 3.20 which states that students agree that teacher stimulates their abilities and supports them on how they use it to judge or give opinions on the subject. The more the students are engaged in academics, the more they gain academic satisfaction (Urquijo \& Extremera, 2017). 
Table 3. Frequency of level of students' academic satisfaction

\begin{tabular}{lll}
\hline Category & Frequency & Percentage \\
\hline Least Satisfied & 0 & 0 \\
Fairly Satisfied & 2 & 1.0 \\
Satisfied & 56 & 28.9 \\
Highly Satisfied & 136 & 70.1 \\
TOTAL & $\mathbf{1 9 4}$ & $\mathbf{1 0 0}$ \\
\hline
\end{tabular}

Note. Scale: (1-25) Less Satisfied; (26-50) Fairly Satisfied; (51-75) Satisfied; (76-100) Highly Satisfied.

The table shows that out of 194 respondents there are 136 respondents who are highly satisfied with their academics indicated with a 70.1 percentage. Students must have strong relation in school in order to be encouraged and raise their academic satisfaction (Wilcox \& Nordstokke, 2019). The researchers observed that most of the students that feels comfortable and do not look at the school as a place where in they don't feel freedom, mostly the students are doing their best in school. With that, students may gain academic satisfaction. The second highest percentage is 28.9 percent to indicate that respondents are satisfied with academic satisfaction. The student's satisfaction will increase when they are into such activities in school (Keshavarzi \& Ahmadi, 2013). The respondents are fairly satisfied as indicated with 1.0 percentage. With that, no respondents are least satisfied. Students who are motivated to learn into certain subject will help them to achieve academic satisfaction (Betoret, Rosello, \& Artiga, 2017).

Table 4. Spiritual vocation and academic satisfaction

\begin{tabular}{llll}
\hline & Value & df & Asymp. Sig. (2-sided) \\
\hline Pearson Chi-Square & $2.548^{\mathrm{a}}$ & 6 & .863 \\
N of Valid Cases & 194 & & \\
\hline
\end{tabular}

Note. a. 4 cells $(33.3 \%)$ have expected count less than 5 . The minimum expected count is .32 .

The p-value (.863) is greater than the standard alpha value (0.05). The result presents that the null hypothesis is failed to reject. There is no significant association between students' spiritual vocation and academic satisfaction. The researchers observed that a student with a strong faith with God does not necessarily mean satisfaction of students in their academic. The students' satisfaction in terms of academic only depends on the teachers and the ways they deliver the lessons to the students to learn. The student's spiritual vocation doesn't have an impact on the academic satisfaction of the students. Moreover, the combination of spirituality and academics are not yet proven or studied because there are no enough evidences that can prove the relationship between the student's spiritual vocation and academic satisfaction (Jett, 2010). The spiritual intelligence of the students will result to 
anxiety to those leaders who are in their way of giving them a good academic performance (Howard \& White, 2009). There is a possibility that spirituality will not only give a positive impact to students' satisfaction but also negative effect (Malik \& Naeem, 2010). Moreover, the combination of spirituality and academics are not yet proven or studied because there are no enough evidences that can prove the relationship between the student's spiritual vocation and academic satisfaction (Jett, 2010).

\section{Findings}

After the study conducted, the researcher found out that the senior high school students of Jagobiao National High School are highly knowledgeable in terms of spiritual vocation.

The level of students' academic satisfaction is high because students strongly agreed that they are academically satisfied. Table 2 shows that students strongly agreed because their teacher answered their questions and problems during class. They also strongly agreed that their teacher explained the lessons clearly and well-organized. Their teacher also stimulates their intellectual curiosity and their desire to learn. Moreover, their teacher uses example that would make them appreciate the relevance of the subject.

As stated in the Table 4, the p-value is greater than the standard alpha value which means that the null hypothesis is not rejected there is no significant association between students' spiritual vocation and their academic satisfaction.

\section{Conclusion}

Grade 11 and Grade 12 students in Jagobiao National High School have high knowledge on spiritual vocation. The senior high school students have a positive response wherein they agree that the teachers have their own way of teaching that make them satisfied with their academics. In relation to Astin's theory which is students' involvement theory, students' characteristics towards school, knowledge, attitude, beliefs and values do not have big impact to students' spirituality. However, even though the senior high school students have a high knowledge on spiritual vocation, it does not have any correlation on their academic satisfaction. There is no enough proof that spiritual vocation cans really satisfy students towards their academic aspect.

\section{Recommendation}

The students of senior high school department will become knowledgeable about the study which shall help them to have reliable source in their future research studies.

Teachers of senior high school department need to assess the students' academic satisfaction.

For the parents of the students of the senior high school department helping their children with their difficulties in their subject, must find ways to help them out in learning and gain positive insight as will us satisfaction in learning.

Future researchers will be able to have reliable sources in making research studies that is related to spiritual vocation and students' academic satisfaction. 


\section{References}

Alorani, O. I., \& Alradaydeh, M. F. (2018). Spiritual well-being, perceived social support, and life satisfaction among university students. International Journal of Adolescence and Youth, 23(3), 291-298. https://doi.org/10.1080/02673843.2017.1352522

Anticevic, V., Kardum, G., Klarin, M., Sindik, J., \& Barac., I. (2017). Academic achievement and study satisfaction: the contribution of high school success and personality. International License.

Astin, A. (1984) Alexander Astin's Theory of Involvement. Journal of College Student Development. Retrieved from https://stuedntdevolpmenttheory.we ebly.com/astin.html

Betoret, F. D., Rosello, L. A., \& Artiga, A. G. (2017). Self-efficacy, satisfaction, and academic achievement: the mediator role of students' expectancy-value beliefs. Frontiers in Psychology, 8, 1-12. https://doi.org/10.3389/fpsyg.2017.01193

Bujis, J. A. (2005). Teaching: profession or vocation. Journal of Catholic Education: A Journal of Inquiry and Practice, 8(3), 327-345. https://doi.org/10.15365/joce.0803042013

Butt, B. Z., \& Rehman, K. U. (2010). A study examining the students' satisfaction in higher education. Procedia Social and Behavioral Sciences, 5446-5450. https://doi.org/10.1016/j.sbspro.2010.03.888

Dhaqane, M. K., \& Afrah, N. A. (2016). Satisfaction of students and academic performance in benadir university. Journal of Education and Practice, 7(24), 59-63. Retrieved from http://www.researchgate.net/publication/334290373

Greenway, K. A. (2006). The role of spiritually in purpose in life and in academic engagement. Journal of College and Character, 7(6). https://doi.org/10.2202/1940-1639.1212

Howard, B. B., \& White, S. R. (2019). Spiritual intelligence and transformational leadership: a new theoretical framework. Journal of Curriculum and Instruction, 3(2), 54-67. https://doi.org/10.3776/joci.2009.v3n2p54-67

Holland, J. L. (1959). Holland's Theory of Vocation Choice. Journal of Career Development. Retrieved from https://www.scribd.com/doc/245118627/A-Theory-of-Vocational-Choice-Holland-1959

Hussain, M., Gilani, S. A., \& Afzal, M. (2019). The relationship between academic success and emotional intelligence, psychological empowerment, resilience, spiritual well-being in nursing students. Journal of Health, Medicine and Nursing, 62, 75-81. https://doi.org/10.7176/JHMN

Jett, C. C. (2010). "Many are called, but few are chosen": the role of spiritually and religion in the educational outcomes of "chosen" African and American male mathematics major. The Journal of Negro Education, 79(3), 324-439. https://reserachgate.net/publication/259855315

Kent, B. V., Bradshaw, M., \& Doughterty, K. D. (2016). Attachment to god, vocational 
calling, and worker contentment. Review of Religious Research, 58, 343-364. https://doi.org/10.1007/s13644-016-0250-9

Keshavarzi, A., \& Ahmadi, S. (2013). The study of students' educational satisfaction in Islamic acad university. Procedia Social Behavioral Sciences, 569-573. https://doi.org/10.1016/j.sbspro.2013.06.108

Lazar, A., Davidovitch, N., \& Coren, G. (2016). Gender differences in calling and works spiritually among israeli academic faculty. Journal of International Education Research, 12(3), 87-98. https://doi.org/10.19030/jier.v12i3.9744

Malik, M. E., \& Naeem, B. (2011). Role of spiritually and job satisfaction and organizational commitment among faculty of institutes of higher learning is Pakistan. African Journal of Business Management, 5(4), 1236-1244. https://doi.org/10.5539/ijbm.v5n6p17

Santi, C. (2014). Vocation and spiritual qualities of priest, canon condition for the effective pastoral missionary work. Teologia, 61(4), 138-156. https://www.researchgate.net/publication/321670178

Shields, R. (2008). Nurturing spiritually and vocation: a catholic approach to new teachers induction. Catholic Education: A Journal of Inquiry and Practice, 12(2), 160-175. https://doi.org/10.15365/joce.1202042013

Thompson, D., \& Perrin, C. (2003). Understanding vocation: discerning and responding god's call. The Berkeley Electronic Press, 11, 1-6. http://digitalcommons.pepperdine.edu/leaven/vol11/iss1/11

Urquijo, I., \& Extremera, N. (2017). Academic satisfaction at university: the relationship between emotional intelligence and academic achievement. Electronic Journal of Research in Educational Psychology, 43, 533-573. https://doi.org/10.14204/ejrep.43.16064

Wach, F. S., Karbach, J., Ruffing, S., Brunken, R., \& Spinath, F. (2016). University students' satisfaction with their academic studies: personality and motivation matter. Frontiers in Psychology, 7, 1-12. https://doi.org/10.3389/fpsyg.2016.00055

Weeransinghe, S., \& Fernando, R. L. S. (2014). Students' satisfaction in higher education literature review. American Journal of Educational Research, 5(5), 533-539.

Wilcox, G., \& Nordstokke, D. (2019). Predictors of university student satisfaction with life, academic self-efficacy, and achievement in the first year. Canadian Journal of Higher Education, 49(1), 104-124. https://doi.org/10.7202/1060826ar

William, O. B., \& Isaac, O. O. (2016). Student spirituality and academic performance: a vase study of kwame Nkrumah university of science and technology (knust), ghana. British Journal of Education, Society, and Behavioral Science, 17(4), 1-13. https://doi.org/10.9734/BJESBS/2016/27910

\section{Glossary}

Spiritual Vocation is work of person to praise or follow the command of our lord. 


\section{Macrothink}

Academic Satisfaction refers to the students' expectations towards their academic, and it is also one of the most important factors that students have.

\section{Appendix A}

Appendix 1: Survey Questionnaire for the Satisfaction of Students in Academics.

Instruction: This questionnaire will help determine the association between spiritual vocation and academic satisfaction. Please answer the questions honestly by giving the NCAE result in spiritual vocation for part 1 and by rating your answer using the rating scales given below for part 2. Your answer will be kept confidentially to avoid invasion of false information and will be acknowledged and appreciated.

Part 1 NCAE Percentile Score in Spiritual Vocation:

Part 2 Academic Satisfaction

\section{Academic Satisfaction}

$\begin{array}{llll}4 & 3 & 2 & 1\end{array}$

1. Teacher stimulates me to understand information.

2. Teacher make it possible for us to achieve learning objectives.

3. Teacher answers question and problems during class.

4. Teacher methods or strategies in teaching are effective.

5. Teacher clearly define the subject objectives.

6. Teacher uses example that would make me appreciate the relevance of the subject.

7. Teacher stimulates my abilities and support them on how I use it to judge or give opinions on the subject.

8. Teacher is available for questions even if it is not a class hours.

9. Teacher explain about the subject is clear and well-organized.

10. Teacher stimulate my intellectual curiosity and my desire to learn.

\section{Copyrights}

Copyright for this article is retained by the author(s), with first publication rights granted to the journal.

This is an open-access article distributed under the terms and conditions of the Creative Commons Attribution license (http://creativecommons.org/licenses/by/4.0/). 